\title{
PENERAPAN PROGRAM REVITALISASI POSKESTREN MELALUI PENINGKATAN PERILAKU HIDUP BERSIH SEHAT (PHBS) PADA SANTRI/WATI DI PONDOK PESANTREN DARUL MUTTAQIN
}

\author{
Ermaya Sari Bayu Ningsih"1) \\ 1)Program Studi Ners, Institut Medika drg. Suherman, Bekasi, Jawa Barat, Indonesia \\ Corresponding author : Ermaya Sari Bayu Ningsih \\ E-mail : mayapendi3969@gmail.com
}

Diterima 11 November 2021, Disetujui 28 November 2021

\begin{abstract}
ABSTRAK
Poskestren merupakan upaya meningkatkan derajat kesehatan santri dipondok pesantren dengan mengutakan upaya promotif dan preventif dalam perilaku hidup bersih dan sehat. Tujuan pengabdian masyarakat adalah mengoptimalkan pos kesehatan pesantren untuk meningkatkan perilaku hidup bersih dan sehat bagi santri di lingkungan pondok pesantren Darul Muttaqin Cibarusa-Bekasi. Pendekatan pada pengabdian masyarakat berbasis penggerakan peran masyarakat pesantren untuk meningkatkan pengetahuan, sikap, perilaku dengan membentuk kegiatan pelatihan dan pendampingan kader pos kesehatan pesantren sebanyak 15 orang dengan metode cerama, diskusi dan praktek langsung. Hasil pengabdian masyarakat terbentuknya program pos kesehatan pesantren dengan tahapan input, proses, output. Diharapkan dukungan dari berbagai pihak yaitu pondok pesantren, puskesmas dan stakeholder untuk terwujudnya program pos kesehatan pesantren
\end{abstract}

Kata kunci: poskestren; perilaku; hidup; bersih; sehat

\begin{abstract}
Healthcare post boarding school is efforts to improve health of students in Islamic boarding schools with preventive and promotional efforts in clean and healthy living. The purpose of the community is to optimize the use of healthcare post islamic boarding schools to implement clean and healthy environment in islamic boarding schools of Darul Muttaqin Cibarusa Bekasi. Closer look at community devotion motivation of islamic boarding schools in order to increase the role of people, attitude, behavior by forming training activities and providing health-related assistance to health post member islamic boarding schools with the methods of lecture as many as 15 , discussion and the practice of directly. The devotion of the public health posts boarding with input stage, process, output. The center is expected to support from various parties and, namely, Islamic boarding schools, stakeholders to the center and a medical post-boarding.
\end{abstract}

Keywords: poskestren; behavior; life; clean; healthy.

\section{PENDAHULUAN}

Pondok pesantren merupakan salah satu institusi pendidikan keagamaan Islam tertua di Indonesia. Karena itu dari sisi historis, pesantren tidak hanya identik dengan makna keislaman, tetapi juga mengandung makna keaslian Indonesia. Menurut Data Emis 2015/2016 dalam Fahham, 2019, jumlah pondok pesantren yang besar dan tersebar di seluruh provinsi di Indonesia sebanyak 28.984 pondok pesantren dengan jumlah santri sebanyak 4.290.626. Pondok Pesantren merupakan salah satu bentuk lembaga Pendidikan keagamaan yang tumbuh dan berkembang dari oleh dan untuk masyarakat yang berperan penting dalam pengembangan sumber daya manusia, diharapkan para santri dan para pemimpin serta pengelola pondok pesantren, tidak saja mahir dalam aspek pembangunan moral dan spiritual dengan intelektual yang bernuansa agamis, namun dapat pula menjadi motor penggerak, motivator dan inovator dalam pembangunan kesehatan, serta menjadi teladan dalam berperilaku hidup bersih dan sehat bagi masyarakat sekitar (Kemenkes RI, 2013).

Pondok pesantren juga merupakan salah satu lembaga pendidikan formal di Indonesia yang metode pembelajarannya berbasis agama Islam. Banyaknya Pondok pesantren di seluruh wilayah Indonesia, karena jumlahnya cukup besar mencapai 27.218 lembaga. Satu pondok pesantren bisa memiliki 500 hingga 1000 orang santri yang akan tinggal 
bersama selama kurun waktu tertentu. Santri yang belajar di pondok pesantren memiliki latarbelakang yang sangat bervariasi dari usia, sosial ekonomi, pendidikan dan perilaku. Kondisi pesantren yang sebagian besar masih belum memiliki fasilitas yang mencukupi memungkinkan munculnya banyak penyakit menular seperti skabies (gudig), konjungtivitis, kutu rambut, diare, dan lain sebagainya. Pondok pesantren dinilai masih perlu mendapat perhatian yang lebih dalam bidang kesehatan, baik berupa akses pelayanan kesehatan, kesehatan lingkungan maupun perilaku hidup sehat. Berdasarkan Peraturan Menteri Kesehatan RI No.1(2013), memberikan pedoman untuk dibentuknya POSKESTREN (Pos Kesehatan Pesantren) dalam upaya meningkatkan derajat kesehatan santri di pondok pesantren dengan mengutamakan upaya promotif dan preventif. Salah satu yang ditekankan dalam hal ini adalah Perilaku Hidup Bersih dan Sehat atau (PHBS), sehingga dalam masalah kesehatan perlu ada penanganan yang serius dalam upaya mewujudkan masyarakat pondok pesantren yang sehat, untuk itu PHBS di lingkungan pondok pesantren harus diterapkan (Rahmawati, 2016).

Mengingat pondok pesantren telah tumbuh dan berkembang hampir di seluruh daerah, maka diharapkan kegiatan ini dapat menyebar secara merata di seluruh Indonesia. Pada umumnya santri yang belajar di pondok pesantren berusia antara 7-19 tahun, dan di beberapa pondok pesantren lainnya menampung santri berusia dewasa. Poskestren merupakan bagian integral dari UKS, di mana sasaran UKS adalah seluruh warga sekolah mulai dari taman kanak-kanak hingga sekolah lanjutan menengah, yang meliputi sekolah umum, keguruan, Sekolah Luar Biasa (SLB), termasuk pondok pesantren, baik jalur sekolah maupun luar sekolah. Bila dilihat dari sisi kesehatan, pada umumnya kondisi kesehatan di lingkungan pondok pesantren masih memerlukan perhatian dari berbagai pihak terkait, baik dalam aspek akses pelayanan kesehatan, berperilaku sehat maupun aspek kesehatan lingkungannya. Salah satu upaya untuk mendekatkan pelayanan kesehatan bagi warga pondok pesantren adalah menumbuh kembangkan Poskestren, untuk memfasilitasi para petugas dan pemangku kepentingan (stakeholders) terkait lainnya, perlu adanya pedoman praktis yang dapat dijadikan acuan dalam melaksanakan tugasnya. Melalui Pedoman Penyelenggaraan dan Pembinaan Pos Kesehatan Pesantren (Poskestren) ini, diharapkan dapat dijadikan acuan dalam pembinaan kesehatan di pondok pesantren dan upaya menumbuhkembangkan Poskestren (Kesehatan, 2013).

Pada umumnya kondisi kesehatan di lingkungan pondok pesantren masih memerlukan perhatian dari pelbagai pihak, baik dalam aspek pelayanan kesehatan, perilaku sehat maupun aspek kesehatan lingkungannya. Berikut beberapa poin permasalahan kesehatan secara umum di pondok pesantren. (1) Berkaitan dengan kesehatan lingkungan: (a) sampah yang berserakan di lingkungan pesantren (b) lantai asrama jarang dipel (c) bak mandi jarang dikuras dan (e) kasur tidak dijemur. (2) Bekaitan dengan masalah tingkah laku: (a) piring tidak segera dicuci sebelum dan sesudah makan (b) sisa makanan yang berserakan di asrama (c) pakaian yang sudah digunakan bergantungan di dalam asrama (d) santri tidur di lantai, tanpa selimut dan alas tidur (e) ember sabun, sepatu dan sandal diletakkan sembarangan di dalam asrama (f) bantal sering dipakai bersama-sama dan (g) sesudah Buang Air Besar (BAB) tidak cuci tangan dengan sabun. (3) Berkaitan dengan masalah gizi: (a) mie instan dijadikan makanan pokok (b) menu makanan kurang bervariasi (c) santri tidak sarapan pagi (d) mengambil porsi makanan yang tidak sesuai, dan (4) Berkaitan dengan masalah sarana dan prasarana: (a) ruang asrama tidak sesuai dengan jumlah penghuni dan (b) kurangnya tempat menjemur pakaian (Muslim, 2012 dalam (A. Nur, 2015).

$\begin{array}{rrrr} & \text { Berdasarkan } & \text { Keputusan Bersama } \\ \text { Menteri } & \text { Kesehatan, } & \text { Menteri Agama dan } \\ \text { Menteri } & \text { dalam } & \text { Negeri } & \text { No. }\end{array}$
1067/Menkes/SKB/VIII/2002, Nomor 385 Tahun 2002 dan Nomor 37 Tahun 2002 tentang Peningkatan Kesehatan Pondok Pesantren dan Instituti Keagamaan lainnya. Selanjutnya pada tahun 2006 Menteri Kesehatan menetapkan Keputusan Menteri Kesehatan RI No 867/Menkes/SK/X/2006 tentang Pedoman Penyelenggaraan dan Poskestren untuk mengatasi masalah-masalah penyakit yang paling sering diderita oleh warga pondok pesantren, melalui wawancara yang dilakukan diperoleh data, yaitu: scabies, diare, sesak nafas, batuk pilek dan penyakit lainya seperti gangguan pencernaan. Untuk itu, salah satu upaya mendekatkan pelayanan kesehatan bagi warga ponok pesantren adalah menumbuhkembangkan poskestren (D. Nur, Purqoti, \& Rusiana, 2015).

Pondok Pesantren Tarbiyatul Fallah Nurul yang berada di daerah Kp Cibucil Desa Sukamanah Kecamanatan Jonggol Jonggol Jawa Barat, Indonesia 16830, merupakan salah satu Pondok yang memiliki santri cukup banyak dan hampir setiap tahun terjadi keluhan kesehatan pada kulit, sehingga perlu adanya 
upaya penanganan untuk menurunkan risiko terjadinya keluhan penyakit kulit. Melalui Revitalisasi Poskestren dan Pembinaan mengenai PHBS akan dilakukan untuk dapat mengupayakan kesehatan bagi masyarakat di lingkungan pesantren. Poskestren merupakan salah satu usaha kesehatan yang bisa dilakukan oleh masyarakat di lingkungan Pesantren dengan mengutamakan pelayanan promotif (peningkatan) dan preventif (pencegahan), dan juga dengan aspek kuratif (pengobatan) dan rehabilitatif (pemulihan kesehatan) dengan binaan puskesmas setempat. Tujuan Poskestren adalah untuk meningkatkan pengetahuan dan kesadaran santri, guru, dan ustadz tentang pentingnya kesehatan, meningkatkan kesadaran untuk melaksanakan Perilaku Hidup Bersih dan Sehat, dan meningkatkan kemauan dan kemampuan untuk melindungi diri berbagai penyakit (Ardian, 2015).

\begin{tabular}{ccc}
\multicolumn{2}{c}{ Revitalisasi } & Poskestren menurut \\
Laretna & $(2015)$ & merupakan proses
\end{tabular} pengulangan, upaya, dan usaha untuk melaukan perbaikan kali dari kekurangan yang ada sebelumnya dan di harapkan bisa meningkatkan kesehatan bagi para masyarakat atau para santri yang ada di Pesantren. Maka dari itu program Poskestren sangat penting guna meningkatkan kepedulian warga pesantren akan permasalahan yang ada di sekitar sesuai dengan permasalahan masingmasing pondok. (Siti Aisyah, 2017). Tujuan Pelaksanaan pengabdian masyarakat ini bertujuan untuk mengoptimalkan pos kesehatan pesantren untuk meningkatkan perilaku hidup bersih dan sehat (PHBS) bagi santri di lingkungan pondok pesantren

\section{METODE}

Pendekatan pada pengabdian masyarakat berbasis penggerakan peran masyarakat pesantren untuk meningkatkan pengetahuan, sikap, perilaku dengan membentuk kegiatan pelatihan dan pendampingan kader pos kesehatan pesantren sebanyak 15 orang dengan metode cerama, diskusi dan praktek langsung. Pelaksanaan dalam pengabdian masyarakat ini dilakukan dengan beberapa tahapan yaitu tahapan input (rekrutmen kader, pemilihan sarana, dukungan pendanaan dan dukungan stakeholder); tahapan proses (frekuensi pertemuan, frekuensi penyuluhan dan frekuensi penilaian); tahapan output (terbentuknya kader poskestren, terbentuknya program poskestren seperti Gerakan jum'at bersih, Kawasan bebas rokok, kebersihan perorangan dan Kawasan bebas sampah, Adanya dana sehat dan
Kerjasama terkait jumlah rujukan santri dan santriwati).

\section{HASIL DAN PEMBAHASAN}

Pesantren Darul Muttaqin Cibarusa-Bekasi. Pondok pesantren menanamkan dasar-dasar agama baik yang bersifat ibadah maupun bersifat sosial, para santri dan santriwati dididik mampu memahami kitab karya khazanah ulama yang bersumber pada Al-Qur'an dan Hadis (As-Sunnah), ljma' dan Qiyas. Banyak kita ketahui permasalahan remaja di masyarakat salah satunya perilaku kekerasan, seks bebas, NAPZA yang menjadi masalah sehingga dengan remaja hidup dipondok dan memahami agama mampu menghindari masalah yang dihadapi remaja (Ermaya Sari Bayu Ningsih, 2018).

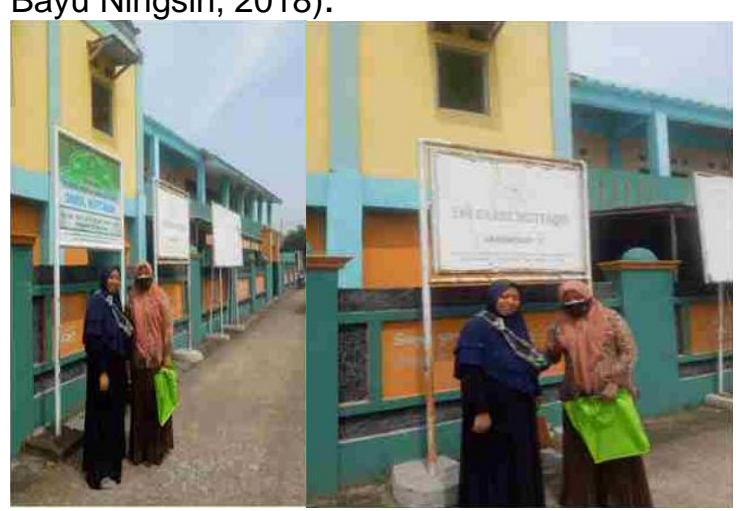

Gambar 3. Akreditasi "A" Pada YPI Darul Muttaqin, Cibarusah-Kabupaten Bekasi

\section{INPUT (Masukan)}

Terdapat beberapa aspek pada katagori sebagai masukan (input) dalam pelaksanaan program pos kesehatan pesantren (POSKESTREN) di Pondok Pesantren Darul Muttaqin Cibarusa-Bekasi.

a. Rekrutment Kader

Pemilihan pengurus dan kader Poskestren dilakukan secara musyawarah mufakat, sesuai dengan tata cara dan kriteria yang berlaku, yang diserahkan kepada internal pondok pesantren, pengajuan program pos kesehatan pesantren dengan membuat proposal terkait kegiatan ini. Kader di pondok pesantren Darul Muttaqin akan dibentuk dan dilakukan pemilihan secara mufakat dengan komitmen yang baik untuk calon kader. Jumlah calon kader yang terdapat di pondok pesantren adalah sebanyak lima belas orang yang merupakan pengurus asrama di pondok pesantren Darul Muttaqin. 


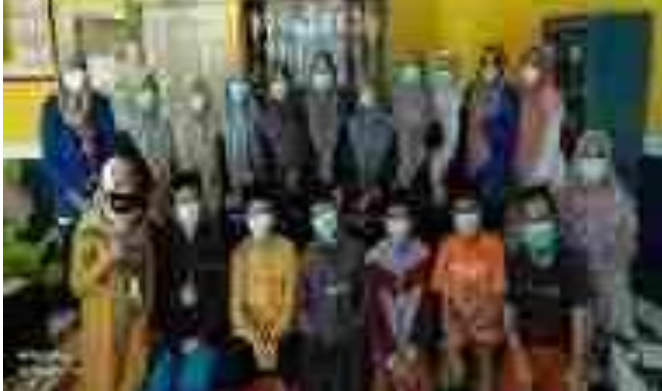

Gambar 4. Pemilihan Kader Poskestren di Pondok Pesantren Darul Muttaqin

Ketua yang dipilih sesuai mufakat bersama adalah Azzar Nusi dan ketua akan mengajukan proposal untuk keterlaksanaan program poskestren di pondok pesantren Darul Muttaqin.

b. Pemilihan Sarana

Poskestren belum bisa diputuskan pada saat pelaksanaan pengabdian masyarakat karena yayasan belum bisa mengikuti kegiatan, sehingga akan ditindak lanjuti untuk mendapatkan dukungan. Mursyid (2003) menyatakan bahwa pelaksanaan suatu program selalu membutuhkan berbagai sarana dan prasarana yang mendukung sehingga program tersebut dapat terlaksana sesuai dengan yang telah direncanakan (A. Nur, 2015).

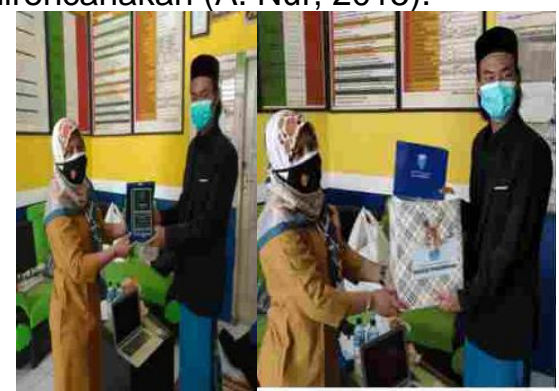

Gambar 5. Wujud Kerjasama antara IMSD dan Ponpes darul Muttaqin.

Harapan dengan adanya kerjasama antara Institut Medika Drg.Suherman yang pada saat ini sudah alih bentuk menjadi Universitas Medika Suherman dengan pondok pesantren Darul Muttaqin dapat mempermudah terbentuknya program poskestren tersebut.

c. Dukungan Pendanaan

Perlu dipikirkan bersama dengan akan terbentuknya program poskestren di pondok pesantren Darul Muttaqin sehingga dukungan pendanaan layanan Kesehatan poskestren. Pendanaan poskestren dapat bersumber dari eksternal dan internal, dana eksternal yang dihasilkan melalui bantuan dari luar pondok pesantren antara lain dari dana program pemerintah daerah, dana bantuan dari institusi lainnya.

d. Dukungan Stakeholder

Dukungan dari berbagai pihak (stakeholder) sangat diperlukan dalam keterlaksanaannya program poskestren dan untuk mencapai peran dan fungsi pos Kesehatan pesantren maka adanya langkah kerjasama dari berbagai pihak pemerintah daerah, Puskesmas, RS dan Institusi Kesehatan.

\section{PROCESS (Proses)}

Kegiatan penyuluhan merupakan kegiatan yang bersifat integratif untuk semua kegiatan program puskesmas, sehingga semua staf puskesmas harus mampu (idealnya) melaksanakannya (every body should do it), baik yang sasarannya individu pasien maupun kelompok-kelompok masyarakat sasaran program, dengan hal ini dapat dikatakan bahwa keterlaksanaan program poskestren harus melibatkan puskesmas yang sesuai dengan program kerjanya.

\section{a. Frekuensi Pertemuan}

Pengamdian masyarakat ini memberikan arahan untuk melakukan kerjasama antara pondok pesantren dengan puskesmas setempat. Perencanaan yang dibuat akan dilakukan sebulan sekali yaitu antar pengurus pesantren dengan pimpinan untuk membahas segala sesuatu yang berhubungan dengan perkembangan pesantren, salah satu yang dibahas adalah masalah kesehatan pesantren, sedangkan pertemuan antara pihak puskesmas dengan pesantren dari hasil kerjasama yang akan direncanakan sekali dalam setahun yaitu pada saat kegiatan penjaringan di awal ajaran baru. Arahan yang diberikan kepada calon kader untuk menumbuhkan semangat, pada pengabdian masyarakat yang dilakukan oleh dosen dalam meningkatkan motivasi kader dalam mensukseskan program pos kesehatan pesantren (poskestren) di pondok pesantren Darul Muttaqin. 


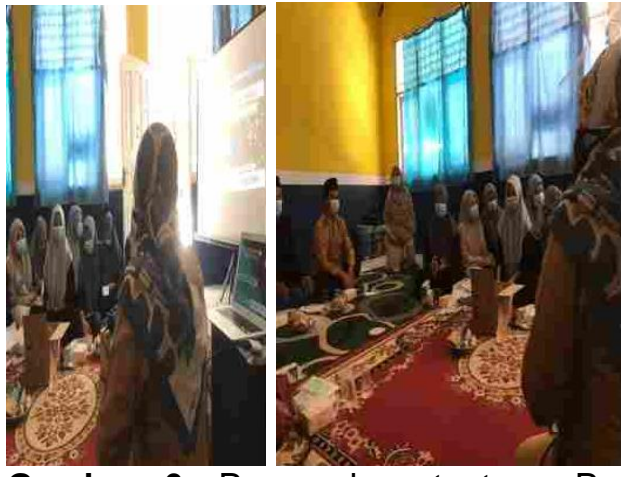

Gambar 6. Pengarahan tentang Pos Kesehatan Pesantren (Poskestren)

b. Frekuensi Penyuluhan

Melakukan pendekatan dengan memberikan penyuluhan merupakan upaya awal dalam mewujudkan terbentuknya poskestren di pondok pesantren Darul Muttaqin. Pengabdian masyarakat yang dilakukan oleh dosen Institut Medika Drg Suherman dengan memberikan penyuluhan dan penempelan poster-poster disetiap titik yang dapat dibaca dan dipahami kader. Penyuluhan ini juga menitik beratkan pada keaktifan kader untuk melakukan pendekatan kepada seluruh santri dan santriwati dalam mensukseskan program poskestren di pondok pesantren Darul Muttaqin Cibarusa-Bekasi.

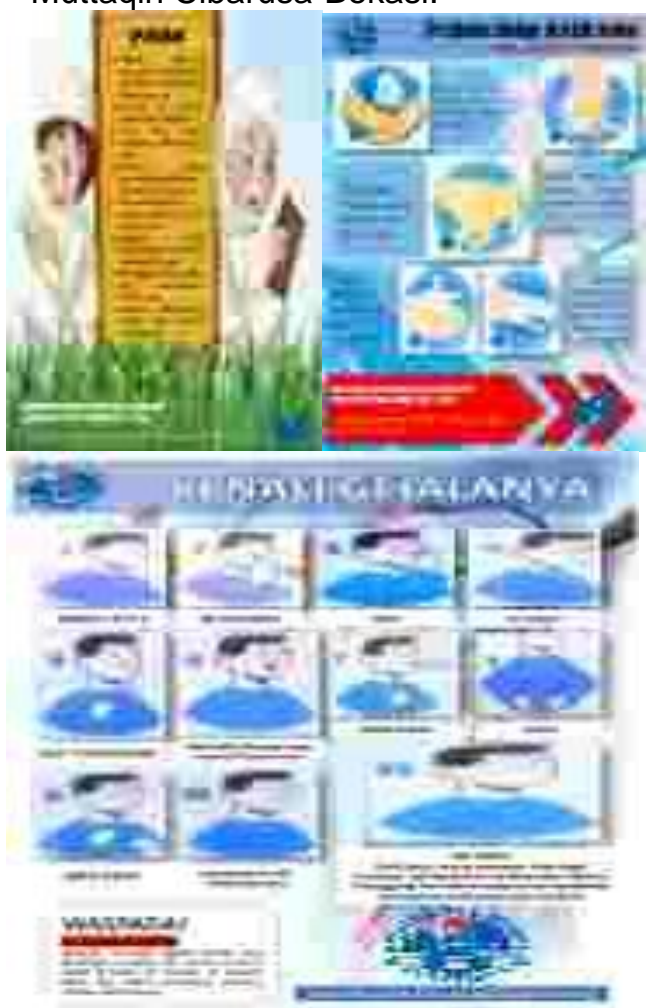

Gambar 7. Poster-poster Kesehatan Pengabdian Masyarakat c. Frekuensi Pembinaan

Pembinaan adalah suatu tindakan, proses, hasil, atau pernyataan menjadi lebih baik. Dalam hal ini menunjukkan adanya kemajuan, peningkatan, pertumbuhan, evolusi atas berbagai kemungkinan, berkembang, atau peningkatan atas sesuatu. Ada dua unsur dari pengertian ini yakni pembinaan itu sendiri bisa berupa suatu tindakan, proses, atau pernyataan dari suatu tujuan, dan ke dua pembinaan itu bisa menunjukkan kepada "perbaikan" atas sesuatu (Thoha, 2003 dalam (A. Nur, 2015). Pembinaan Poskestren dilaksanakan secara terpadu oleh puskesmas dan stakeholders terkait lainnya yang dilakukan secara berkala, baik langsung maupun tidak langsung.

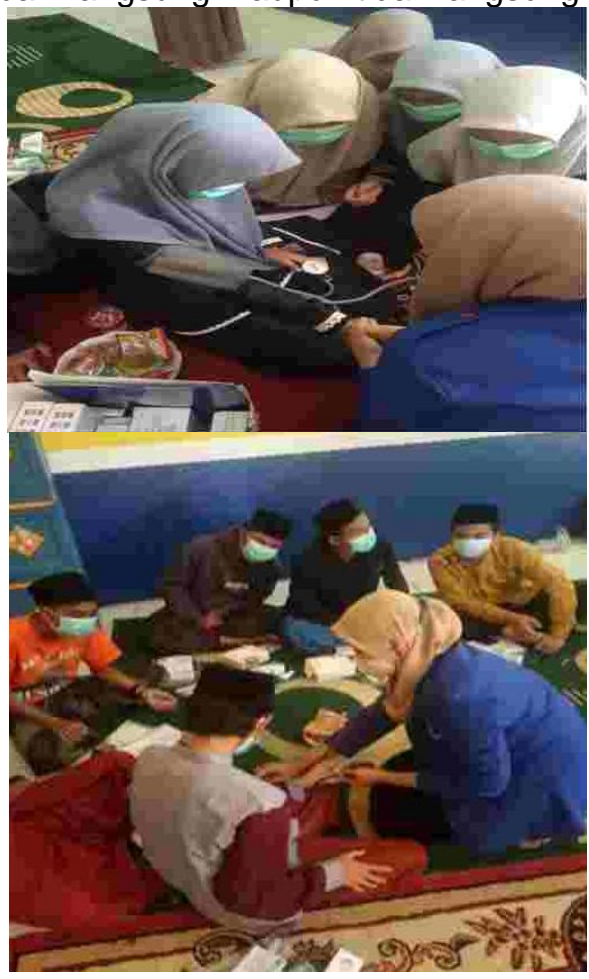

Gambar 8. Pembinaan Kader

Poskestren Pondok Pesantren Darul Muttaqin

Kegiatan pembinaan yang akan dilakukan di Poskestren Pesantren Darul Muttaqin yaitu pembinaan para kader kesehatan dengan bimbingan dan koordinasi dengan pihak puskesmas. Pesantren melakukan pembinaan secara mandiri. Sedangkan pembinaan administrasi dan manajemen poskestren akan dilakukan dengan dukungan puskesmas setempat. Thoha (2003) mengatakan bahwa pembinaan tidaklah hanya "sesuatu yang dikerjakan untuk pencapaian keadaan organisasi yang 
lebih baik", melainkan merupakan suatu jenis proses perubahan, pembaharuan, dan penyempurnaan yang khusus dalam suatu organisasi (Lilleyman, 2018). Kegiatan pembinaan dirasa sangat dibutuhkan mengingat tuntutan masyarakat yang semakin berkembang untuk memperoleh pelayanan kesehatan yang bermutu. Karena inti dari kegiatan pembinaan itu adalah menjadikan sasaran kegiatan pembinaan menjadi mampu tumbuh dan bertambah kecakapannya, keterampilannya, dan pengetahuannya.

\section{OUTPUT (Keluaran)}

\section{a. Terbentuknya Kader Poskestren}

Pondok pesantren yang sehat tentu saja tidak lepas dari peran dari seluruh warga pesantren itu sendiri baik pengurus, guru/ustadz maupun santri. Pemberdayaan santri di pondok pesantren sebagai kader kesehatan merupakan salah satu upaya yang bertujuan untuk memfasilitasi santri untuk mengenal masalah yang ada dalam lingkungan pondok pesantren dan melakukan upaya pencegahan serta upaya memanfaatkan potensi sesuai dengan kondisi pondok pesantren (Rachmawaty et al., 2018).

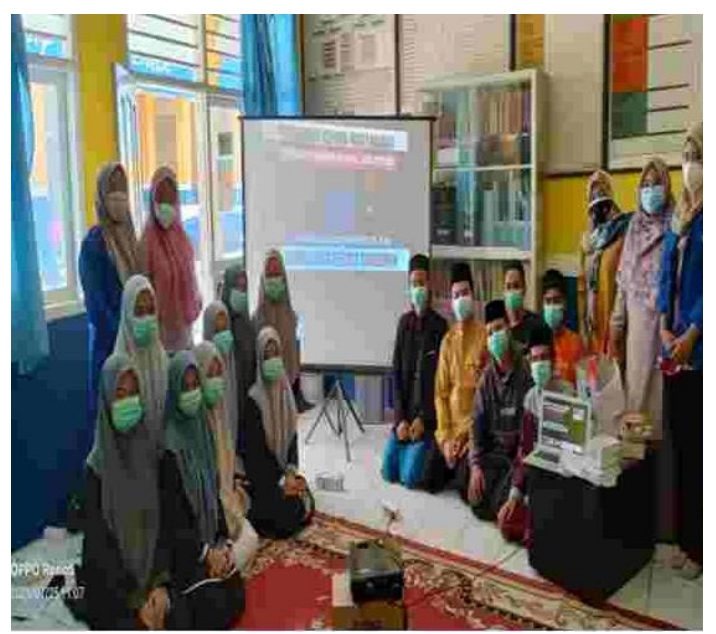

Gambar 10. Pembentukan Calon Kader Poskestren Ponpes Darul Muttaqin

Kader Poskestren dipilih oleh pengurus Poskestren dan santri pondok pesantren yang bersedia secara sukarela, mampu dan memiliki waktu untuk menyelenggarakan kegiatan Poskestren. Kriteria kader Poskestren antara lain sebagai berikut:

1. Berasal dari santri atau alumni pondok pesantren
2. Mempunyai jiwa pelopor, pembaharu dan penggerak masyarakat

3. Bersedia bekerja secara sukarela

4. Telah mengikuti pelatihan/orientasi kader tentang kesehatan.

b. Terbentuknya Program Poskestren

Terbentuknya program-program yang dapat dilaksanakan oleh kader poskestren antara lain:

1. Gerakan jum'at bersih

2. Kawasan bebas rokok

3. Kebersihan perorangan (personal hygiene)

4. Kawasan bebas sampah

c. Adanya Dana Sehat

Terbentuknya dana sehat yang bersumber dari swadaya pondok pesantren, masyarakat, swasta/dunia usaha, pemerintah dan pemerintah daerah. Pemanfaatan dan pengelolaan dana poskestren dapat dilakukan:

1. Pemanfaatan Dana

Dana yang diperoleh Poskestren, digunakan untuk membiayai kegiatan Poskestren, antara lain untuk:

- Biaya operasional dan pemeliharaan Poskestren

- Bantuan biaya rujukan bagi yang membutuhkan

- Biaya peningkatan kapasitas pengelola dan kader Poskestren

- Biaya pengembangan Poskestren.

2. Pengelolaan Dana

Pengelolaan dana dilakukan oleh pengelola dan kader Poskestren. Dana harus disimpan di tempat yang aman. Untuk keperluan biaya rutin disediakan kas kecil yang dipegang oleh kader yang ditunjuk. Setiap pemasukan dan pengeluaran harus dicatat, dikelola dan dilaporkan secara bertanggung jawab.

d. Kerjasama (Jumlah rujukan santri dan santriwati)

Mengembangkan jejaring kerjasama/ kemitraan antara pesantren dengan lintas sektor. Hal ini dilakukan untuk memantapkan kerja sama dengan berbagai unsur terkait lainnya, sehingga dapat menunjang dan mengarahkan perannya dalam pengembangan Poskestren. Aktualisasi dari pengembangan jejaring Poskestren, dapat dilakukan melalui temu jejaring Poskestren, sekurang-kurangnya sekali dalam setahun. Selain untuk 
memantapkan kerja sama, juga diharapkan dapat dijadikan ajang untuk melakukan tukar-menukar pengalaman dan upaya pemecahan masalah yang dihadapi (Surur \& Sholichatun, 2018).

\section{SIMPULAN DAN SARAN}

Berdasarkan hasil pengabdian masyarakat, kesimpulan yang dapat diambil adalah sebagai berikut: 1). Program Poskestren belum terbentuk di Pondok Pesantren Darul Muttaqin Cibarusa-Bekasi, sehingga pembentukan program Poskestren akan diajukan melalui proposal yang ditujukan ke YPI Darul Muttaqin untuk mendapatkan persetujuan dibentuknya program ini, 2). Metode pengabdian masyarakat yang dilakukan pada pondok pesantren Darul muttaqin dengan melakukan recruitment calon kader poskestren sehingga proposal pengajuan akan dilakukan oleh calon kader, pelatihan dan pendampingan kader tentang pertolongan pertama dan deteksi dini kesehatan dengan pemantauan tanda-tanda vital serta menilai status gizi, pelatihan dan pendampingan dalam berperilaku hidup bersih dan sehat (PHBS) dan pelatihan dan pendampingandalam survei mawas diri, 3). Pelaksanaan dalam pengabdian masyarakat ini dilakukan dengan beberapa tahapan yaitu tahapan input (rekrutmen kader, pemilihan sarana, dukungan pendanaan dan dukungan stakeholder); tahapan proses (frekuensi pertemuan, frekuensi penyuluhan dan frekuensi penilaian); tahapan output (terbentuknya kader poskestren, terbentuknya program poskestren seperti Gerakan jum'at bersih, Kawasan bebas rokok, kebersihan perorangan dan Kawasan bebas sampah, Adanya dana sehat dan Kerjasama terkait jumlah rujukan santri dan santriwati).

\section{UCAPAN TERIMAKASIH}

Rasa syukur kehadirat Allah SWT atas karunia hidup, ilmu yang dianugerahkan-NYA sehingga penulis dapat menyelesaikan penelitian ini. Selama persiapan, pelaksanaan, penyusunan sampai penyelesaian penelitian penulis banyak mendapat bantuan, bimbingan, arahan, dan motivasi dari berbagai pihak baik secara moril maupun material, terimakasih, penghargaan setinggi-tingginya, khususnya kepada kepada: Yayasan Medika Bahagia yang telah memberikan bantuan dana yang sudah diberikan kepada seluruh dosen untuk melakukan penelitian dan pengmas, kepada ibu Rektor, Ketua LPMI, LPPM dan Seluruh Civitas di Universitas Medika Suherman, Terima kasih khususnya kepada responden dan SMAN $X$ yang telah bersedia menjadi tempat penelitian, serta suami dan keluarga yang telah mendukung peneliti.

\section{DAFTAR RUJUKAN}

Ardian. (2015). Revitalisasi Poskestren sebagai Upaya untuk Menurunkan Keleuhan Gangguan Kulit Pada Santri di Pondok As Alafiyyah. Skripsi, 1-27.

Arifin. (2018). Hubungan Personal Hygiene dan Sanitasi Lingkungan dengan Kejadian Penyakit Scabies di Pondok Pesanten Marifatul Beingin Kabupaten Ngawi. Journal of Materials Processing Technology, 1(1), 1-8. Retrieved from http://dx.doi.org/10.1016/i.cirp.2016.06 .001\%0Ahttp://dx.doi.org/10.1016/i.po wtec.2016.12.055\%0Ahttps://doi.org/1 0.1016/j.ijfatigue.2019.02.006\%0Ahttp s://doi.org/10.1016/j.matlet.2019.04.02 4\%0Ahttps://doi.org/10.1016/j.matlet.2 019.127252\%0Ahttp://dx.doi.o

BKKBN, BPS, Kementrian Kesehatan, U. (2018). Survei Demografi dan Kesehatan Indonesia 2017 Profinsi DKI Jakarta. 271. Retrieved from http://demografi.bps.go.id/phpfiletree/s dki/BahanAjarSDKI2007/Lainnya/Publi \begin{tabular}{lll}
\hline kasi & SDKI & 2002-
\end{tabular} 2003/RingkasanSDKI02-03.pdf

Candra, \& Permatasari, E. (2016). Hubungan Personal Hygiene Dengan Kejadian Penyakit Kulit Pada Tuna Wisma Di Kecamatan Jelbuk Kabupaten Jember. Perpustakaan Dijital Universitas Muhammaddiyah Jember, (personal hygiene), 1-9. Retrieved from http://digilib.unmuhjember.ac.id/gdl.ph p?mod=browse\&op=read\&id=umj-1xtiasnoraca-3497

Ermaya Sari Bayu Ningsih, S. H. A. (2018). Kekerasan seksual pada anak di Kabupaten Karawang. Jurnal Ikatan Bldan Indonesia.

Fahham, A. M. (2019). Sanitasi dan Dampaknya bagi Kesehatan: Studi dari Pesantren. Aspirasi: Jurnal MasalahMasalah Sosial, 10(1), 33-47. https://doi.org/10.46807/aspirasi.v10i1. $\underline{1230}$

Fatmawati, T. Y.; N. E. S. (2016). Perilaku Hidup Bersih dan Sehat Santri Pondok Pesantren AS' AD dan Pondok Pesantren AL HIDAYAH. Jurnal Psikologi Jambi, 1(1), 29-35.

Ihtiaringtyas, S., Mulyaningsih, B., \& Umniyati, S. R. (2019). Faktor Risiko Penularan Penyakit Skabies pada Santri di Pondok Pesantren An Nawawi Berjan Kecamatan Gebang Kabupaten Purworejo Jawa Tengah. Balaba: Jurnal Litbang Pengendalian Penyakit 
Bersumber Binatang Banjarnegara, 83-90.

https://doi.org/10.22435/blb.v15i1.1784

Kemenkes RI. (2013). Peraturan Menteri Kesehatan Nomor 1 Tahun 2013 tentang Pedoman Penyelenggaraan dan Pembinaan Pos Kesehatan Pesantren. Departemen Kementerian Kesehatan Republik Indonesia, 1-9. Retrieved from http://promkes.kemkes.go.id/download /isc/files51071Pedoman Penyelengga raan dan Pembinaan Pos Kesehata n Pesantren.pdf

Kesehatan, M. (2013). Pedoman Penyelenggaraan dan Pembinaan Pos Kesehatan Pesantren. UndangUndang, (163), 5-27. Retrieved from www.djpp.kemenkumham.go.id

Lilleyman, J. (2018). Profil Kesehatan Indonesia. In Journal of Clinical Pathology (Vol. https://doi.org/10.1136/jcp.40.5.591-b

Nur, A. (2015). Kajian Pelaksanaan Program Pos Kesehatan (Poskestren) di Pondok Pesantren Ar-Raudhatul Hasanah Medan Provinsi Sumatera Utara. Skripsi, 7-37.

Nur, D., Purqoti, S., \& Rusiana, H. P. (2015). Potensi Santri Dalam Pelaksanaan Perilaku Hidup Bersih Dan Sehat (Phbs) Pada Pondok Pesantren.

Rachmawaty, F. J., Rosmelia, Rochmah, F. S. N., \& Lusiyana, N. (2018). Peran Rekestren (Relawan Kesehatan Pesantren) Dalam Meningkatkan Derajat Kesehatan Pondok Pesantren. 1-6.

Rahmawati, A. P. (2016). Faktor-Faktor yang Berpengaruh dengan Perilaku Pencegahan Penularan HIV/AIDS Pada Mahasiswa GAY di Kota Semarang. Jurusan IImu Kesehatan Masyarakat Fakultas IImu Keolahragaan Universitas Negeri Semarang, (Skripsi). Retrieved from https://lib.unnes.ac.id/28503/1/641141 2100.pdf

Rif'ah, E. (2019). Pemberdayaan Pusat Kesehatan Pesantren (Poskestren) Untuk Meningkatkan Perilaku Hidup Bersih Dan Sehat. Warta Pengabdian, 13. https://doi.org/10.19184/wrtp.v13i3.118 $\underline{62}$

Siti Aisyah. (2017). Analysis of poskestren implementation program in facing scabies disease at pondok pesantren al-aziziyah west lombok province west nusa tenggara. 13-46.
Sofia, D., \& Widad, S. (2016). SURVEY OF CLEAN AND HEALTHY LIFE BEHAVIOUR IN SANTRI Penelitian Rahadian dalam Ikhwanudin. Oksitosin, III(2), 113-117.

Supriatna, L. D., Indasah, I., \& Suhita, B. M. (2020). Program promotif poskestren terhadap PHBS santri di pondok pesantren. Holistik Jurnal Kesehatan, 14(3), 332-337. https://doi.org/10.33024/hjk.v14i3.2741

Surur, M., \& Sholichatun, Y. (2018). Pengembangan Panduan Konseling Psikoreligius Untuk Remaja Korban Kekerasan. Jurnal Psikologi Pendidikan Dan Konseling: Jurnal Kajian Psikologi Pendidikan Dan Bimbingan Konseling, 4(2), 137. https://doi.org/10.26858/jpkk.v4i2.7424

Tingkat, H., Phbs, P., \& Yuwanto, M. A. (2005). pada santriwan di pondok pesantren Nurul Islam Kecamatan Sumbersari Kabupaten Jember. Jenis penelitian ini menggunakan penelitian. 5(1), 339346.

Walisongo, D. A. N. P. (2020). Gambaran personal hygiene dan kejadian penyakit kulit di pesantren mathla'ul anwar dan pesantren walisongo. skripsi 